\title{
Comparative Effects of Cocoa Pod Husk and Oil Palm Bunch Ash on Nutrient Uptake, Growth and Dry Matter Yield of Cocoa (Theobroma cacao) in Ibadan, Southwest Nigeria
}

\author{
Olorunfemi Sunday Ojo Akanbi ${ }^{*}$, Amos Olatunde Famaye ${ }^{2}$, Olayinka Olufemi Olaniyi ${ }^{3}$, \\ Rufus Rotimi Ipinmoroti', C. I. Iloyanomo', Beatrice Abanum Nduka ${ }^{3}$, \\ Seun Adewale Adeosun ${ }^{3}$ \\ ${ }^{1}$ Soils and Plant Nutrition Section, Cocoa Research Institute of Nigeria, Ibadan, Nigeria \\ ${ }^{2}$ Agronomy and Soil Division, Cocoa Research Institute of Nigeria, Ibadan, Nigeria \\ ${ }^{3}$ Department of Plant Breeding, Cocoa Research Institute of Nigeria, Ibadan, Nigeria \\ Email: ${ }^{*}$ akanbioso2008@yahoo.com, akanbioso2008@gmail.com
}

Received 9 July 2014; revised 21 August 2014; accepted 21 September 2014

Copyright (C) 2014 by authors and Scientific Research Publishing Inc.

This work is licensed under the Creative Commons Attribution International License (CC BY). http://creativecommons.org/licenses/by/4.0/

\section{(c) (i) Open Access}

\section{Abstract}

The high premium placed on the organically produced cocoa in the international market coupled with its health and environmental benefits necessitated recent focus on research into the use of agricultural wastes as source of nutrients in cocoa (T. cacao) production. The study was carried out at the Cocoa Research Institute of Nigeria (CRIN), Ibadan (Lat. $7^{\circ} 25^{\prime} \mathrm{N}$ Long. $3^{\circ} 25^{\prime} \mathrm{E}$ ), Southwestern, Nigeria during the $2010 / 2011$ seedling production season to compare the effects of NPK (20:10:10) fertilizer, Cocoa Pod Husk and Oil Palm Bunch Ash (CPHA and OPA) on the seedling growth and dry matter yield of cocoa (T. cacao). Equivalent amount of different rates of two nutrients sources CPHA and OPA were applied one month after planting at $0,1,2,3,4$ and $5 \mathrm{t} / \mathrm{ha}$ respectively, recommended rate of $10 \mathrm{~kg} \cdot \mathrm{N}$ of the conventional NPK (20:10:10). Fertilizer was used as reference fertilizer. Results indicated that all the fertilizer materials positively and significantly ( $p>0.05)$ increased the growth parameters considered. The influence of the ash materials irrespective of sources on the nutrient uptake, dry matter yield of cocoa seedlings and shoot to root ratio were either higher than or had a comparable results with the reference fertilizer (NPK 20:10:10). CPHA and OPA applied at a rate of $4 \mathrm{t} / \mathrm{ha}$ significantly $(p>0.05)$ increased the plant height and root length of cocoa seedlings respectively relative to control and in-organic fertilizer

\footnotetext{
"Corresponding author.
}

How to cite this paper: Akanbi, O.S.O., Famaye, A.O., Olaniyi, O.O., Ipinmoroti, R.R., Iloyanomo, C.I., Nduka, B.A. and Adeosun, S.A. (2014) Comparative Effects of Cocoa Pod Husk and Oil Palm Bunch Ash on Nutrient Uptake, Growth and Dry Matter Yield of Cocoa (Theobroma cacao) in Ibadan, Southwest Nigeria. Agricultural Sciences, 5, 1046-1052. 
and could therefore be recommended for the prospective and existing Nigerian cocoa farmers for raising their seedlings in the nursery before transplanting to the field.

\title{
Keywords
}

\author{
Cocoa Pod Husk Ash, Oil Palm Bunch Ash, Dry Matter Yield, Cocoa Seedlings
}

\section{Introduction}

The impact of improving soil fertility is tremendous and leads to marked increase in cocoa production, while ensuring sustainability of cocoa production. It improves soil fertility, reduces soil degradation, enhance vigorous growth and better establishment of cocoa trees. It increases quantity of cocoa beans produced and ensures longevity of cocoa trees. This in turn led to better economic return to farmers and renewed interest in cocoa production [1]. There is therefore an urgent need to combat the problem of soil fertility from different fronts based on proper understanding of the nutrient dynamics of cocoa soils in Nigeria.

Cocoa (Theobroma cacao) is a crop of economic value which contributes $38.5 \%$ to the gross domestic product (GDP) of Nigerian economy (N.E.P.C., 2011). Presently, the current production is put at 370,000 MT with a yield of $270 \mathrm{~kg} / \mathrm{ha}$ [2] which is quite below the current production capacity of Côte d'Ivoire with 1,221,600 MT of cocoa beans and yield of $610 \mathrm{~kg} / \mathrm{ha}$ which had its peak production of 304,000 MT dried cocoa beans in 1970 [2] and dropped to 225,000 MT in 1999. Years of abandonment of the agricultural sector has led to its low production in the country.

The efforts of the government to revive the ailing cocoa sector towards increasing the production through the activities of National Cocoa Development Committee (NCDC) have been faced with challenges. Among these challenges are the low cocoa yield, low soil fertility and ageing cocoa farms. Reports of the soil fertility evaluation across cocoa ecologies in Nigeria country have shown that phosphorous and potassium is limiting [3], hence, the use of fertilizer (Organic and In-organic) has become inevitable. Scarcity and high cost of in-organic fertilizers however, prohibit their use by peasant farmers. Recent reports on fertilizer usage have revealed the potentials of some organic fertilizers as cheap, readily available and environmentally friendly. Ash derived from cocoa pod husk and oil palm bunch have been found as useful source of both micro and macro nutrients for various crops [4] [5]. However, there is dearth of information on the use of cocoa pod husk ash and oil palm bunch ash on the growth and dry matter yield of cocoa seedlings; hence, the needs for this present study. The objective of this work therefore was to assess the effect of cocoa pod husk ash and oil palm bunch ash on the growth and dry matter yield of cocoa in the greenhouse.

\section{Materials and Methods}

A pot experiment was conducted at the greenhouse of Cocoa Research Institute of Nigeria, Ibadan, in the rain forest zone of South western Nigeria during the 2011/2012 growing season to evaluate the effect of Oil Palm Bunch and Cocoa Pod Husk Ash (CPHA and OPA) on the nutrient uptake, growth and dry matter yield of cocoa hybrid (T65/7 X T57/22). The experiment was laid out in a completely randomized design (CRD) in three replications. The treatments consisted of control, CPHA, OPA and NPK 20:10:10 fertilizer respectively. The organic fertilizers (CPHA and OPA) were applied at 1, 2, 3, 4 and 5 tons per hectare while the recommended rate of $10 \mathrm{~kg} \cdot \mathrm{N}$ per hectare was used for NPK 20:10:10. Two cocoa beans were planted per pot filled with sieved plantation soil and later thinned to one plant per pot. Watering was carried out thrice per week throughout the period of the experiment. The fertilizer materials were applied in a ring form four weeks after seedling emergence. Soil samples were collected before and at harvest six months after treatment application for laboratory analysis. Agronomic data such as plant height $(\mathrm{cm})$, stem girth $(\mathrm{mm})$, number of leaf per plant, root length $(\mathrm{cm})$ and leaf area $\left(\mathrm{cm}^{2}\right)$ were collected and later subjected to statistical analysis.

\subsection{Laboratory Routine Soil Analysis}

Soil sample was analyzed for $\mathrm{pH}$ in distilled water of soil to water ratio 1:1 using glass electrode on EIL 7020 $\mathrm{pH}$ meter. Particle size distribution was determined by the hydrometer method using sodium hexa-metaphos- 
phate as dispersing agent. Exchangeable bases ( $\mathrm{K}, \mathrm{Na}$, Ca and $\mathrm{Mg}$ ) were determined by extraction with ammonium acetate $\left(\mathrm{NH}_{4} \mathrm{OAC}\right)$ at soil: water solution ratio 1:10. Potassium, $(\mathrm{K})$, calcium $(\mathrm{Ca})$ and magnesium $(\mathrm{Mg})$ in the extract were read by flame photometer while magnesium was determined by atomic absorption spectrometer (AAS). Soil exchangeable acidity was determined by titration of kcl extracted acidity against $0.05 \mathrm{~N}$ sodium hydroxide to a pink end point using phenolphthalein as an indicator. Cation exchangeable capacity was obtained by summation of exchangeable cations (K, Na and $\mathrm{Mg}$ ) and exchangeable acidity. Available Phosphorous (P) was determined using $0.03 \mathrm{~N} \mathrm{NH}_{4} \mathrm{~F}$ in $0.025 \mathrm{~N} \mathrm{HCL}$ as extractant. Organic carbon (OC) was determined by wet oxidation with sulphuric acid. The experimental design used for the study was a completely randomized design (CRD) in three replications. There were twelve (12) treatments which comprise of Control (no application); NPK (20:10:10); CPHA and OPA at five levels (1, 2, 3, 4 and 5 tons/ha) of application each. Two cocoa beans were planted per pot of $10 \mathrm{~kg}$ soil each. Thinning of cocoa seedlings to one plant per pot was carried out four weeks after planting and treatments were imposed a day later. Equivalent quantity of the fertilizer materials were applied in a ring form $(10 \mathrm{~cm}$ away from the cocoa plants). Initial data were collected immediately after treatment imposition. Agronomic parameters such as plant height $(\mathrm{cm})$, number of leaves per plant, leaf area $\left(\mathrm{cm}^{2}\right)$, stem diameter $(\mathrm{cm})$ and dry matter yield (g/plant) were collected at one (1) month after treatments application. Plant height $(\mathrm{cm})$ was measured using meter rule while number of leaves was counted. Stem diameter $(\mathrm{cm})$ was determined using a Venier calliper. The cocoa seedlings were carefully removed from the container, root washed and parts separated into root, stem and leaf respectively, six months after treatment application.

\subsection{Processing of Organic Material into Ash}

The oil palm bunch and cocoa pod Husk materials were sourced from the oil palm and cocoa processing unit of the Cocoa Research Institute of Nigeria (CRIN), Ibadan. They were sun-dried for three weeks and then burnt into ashes. The ash materials were collected after cooling and bagged into nylon bags.

\subsection{Analysis of the Cocoa Pod Husk and Oil Palm Bunch Ash}

Chemical analysis of the ash sample was carried out in the laboratory using standard procedure [6]. Nutrients in the ash were extracted by washing twice with $0.1 \mathrm{NHcl}$. Available phosphorus (P) was determined colorimetrically by vanodo-molybdate (yellow) method. Potassium (K), Calcium (Ca) and Sodium (Na) were determined by flame photometer while $\mathrm{Mg}$ was determined by atomic absorption spectro-photometer.

\subsection{Data Analysis}

Data generated were subjected to statistical analysis and means separated by Duncan Multiple Range Test at 5\% level of significance.

\section{Results and Discussion}

The physico-chemical properties of soil used for the trial prior planting are presented in Table 1 . The soil contained $682 \mathrm{~g} \cdot \mathrm{kg}^{-1}$ Sand; $140 \mathrm{~g} \cdot \mathrm{kg}^{-1}$ Silt and $178 \mathrm{~g} \cdot \mathrm{kg}^{-1}$ clay. The clay + silt contents of $318 \mathrm{~g} \cdot \mathrm{kg}^{-1}$ soil is found to be sufficient to hold enough soil moisture for sustainable cocoa plant growth and to guard against short dry spell [7]. The soil was slightly acidic with $\mathrm{pH}$ value of 6.41 and low in organic carbon. The organic carbon of 19.2 $\mathrm{g} \cdot \mathrm{kg}^{-1}$ soil was below the $30 \mathrm{~g} \cdot \mathrm{kg}^{-1}$ soil ideal for suitable soil for tree crop production in Nigeria [7]. This on the other hand, suggests the need to increase the soil organic matter (SOM) content to give room for sustainable and optimal cropping on the soil. The total nitrogen $\left(0.75 \mathrm{~g} \cdot \mathrm{kg}^{-1}\right.$ soil $)$ was less than $1.00 \mathrm{~g} \cdot \mathrm{kg}^{-1}$ soil which is considered optimal for most tree crops. Similarly, the level of $\mathrm{K}$, Ca and $\mathrm{Mg}$ contents of $0.61,2.31$ and 0.58 $\mathrm{cmol} \cdot \mathrm{kg}^{-1}$ soil respectively were all very low and below soil critical values of $1.20 ; 8.00$ and $0.80 \mathrm{cmol} \cdot \mathrm{kg}^{-1}$ soil which were considered suitable for cocoa, cashew, coffee, and kola production. This however is an indication that the soil is low in fertility. The general low nutrient content of the soil indicated that the soil could not be cropped for long without fertilizer application for optimal cocoa plant growth and productivity. Hence, the soil would benefit positively from organic materials addition because they contain varying amount of $\mathrm{Ca}$; and $\mathrm{Mg}$ in addition to N, P, and $\mathrm{K}$ which are the only contents of NPK fertilizer.

Table 2 presents data on the nutrient element composition of both the cocoa pod husk ash (CPHA) and the oil palm bunch ash (OPA). CPHA and OPA contained N, P, K in addition to Ca and Mg. The low N contents of the 
Table 1. Physico-chemical properties of Ibadan soil before the trial.

\begin{tabular}{ccc|}
\hline Nutrient Element Composition & Units & Values \\
\hline Nitrogen $(\mathrm{N})$ & $\left(\mathrm{g} \cdot \mathrm{kg}^{-1} \mathrm{soil}\right)$ & 0.75 \\
Phosphorous (P) & $\left(\mathrm{g} \cdot \mathrm{kg}^{-1}\right)$ & 5.74 \\
Potassium (k) & $\left(\mathrm{cmo} \cdot \mathrm{Kg}^{-1}\right)$ & 0.61 \\
Calcium (Ca) & $\left(\mathrm{cmol} \cdot \mathrm{Kg}^{-1}\right)$ & 2.31 \\
Magnesium (Mg) & $\left(\mathrm{cmol} \cdot \mathrm{Kg}^{-1}\right)$ & 0.58 \\
Organic Carbon (OC) & $\left(\mathrm{g} \cdot \mathrm{kg}^{-1}\right)$ & 19.20 \\
PH & - & 6.40 \\
Sand & $\left(\mathrm{g} \cdot \mathrm{kg}^{-1}\right)$ & 682 \\
Silt & $\left(\mathrm{g} \cdot \mathrm{kg}^{-1}\right)$ & 140 \\
Clay & $\left(\mathrm{g} \cdot \mathrm{kg}^{-1}\right)$ & 178 \\
Textural class & Sandy clay loam & \\
\hline
\end{tabular}

Table 2. Nutrient composition of the organic materials.

\begin{tabular}{ccc}
\hline Crop Nutrient Element & CPHA & OPA \\
\hline Organic Carbon $\left(\mathrm{g} \cdot \mathrm{kg}^{-1}\right)$ & 1.00 & 1.7 \\
Nitrogen $\left(\mathrm{g} \cdot \mathrm{kg}^{-1}\right)$ & 0.90 & 0.2 \\
Phosphorous $(\mathrm{g} / \mathrm{kg})$ & 0.50 & 0.2 \\
Potassium $\left(\mathrm{g} \cdot \mathrm{kg}^{-1}\right)$ & 4.30 & 26.5 \\
Calcium $\left(\mathrm{cmol} \cdot \mathrm{kg}^{-1}\right)$ & 0.80 & 6.90 \\
Magnesium $\left(\mathrm{cmol} \cdot \mathrm{kg}^{-1}\right)$ & 0.30 & 3.10 \\
$\mathrm{pH}\left(\mathrm{H}_{2} \mathrm{O}\right)$ & 7.50 & 8.30 \\
\hline
\end{tabular}

CPHA — cocoa Pod Husk Ash; OPA—oil palm bunch ash; g/kg—gramm per kilogramme. $\mathrm{Cmol} / \mathrm{kg}$ — centimol per kilogramme.

ash materials could be adduced to the volatilization of $\mathrm{N}$ during the burning process of the materials [5] The presence of $\mathrm{N}, \mathrm{P}, \mathrm{K}, \mathrm{Ca}$ and $\mathrm{Mg}$ and high $\mathrm{pH}$ of the materials is consistent with the observation of [8] that ash of plant origin including those of cocoa and kola pod husk contained N, P, K, Ca and Mg respectively. Similarly, the high $\mathrm{pH}$ value of the ash materials is an indication that the materials can serve as a good source of liming materials as observed by [9].

The fertilizer materials increased the growth parameters of the cocoa seedlings at all levels of application (Table 3) relative to control and the reference fertilizer (NPK 20:10:10). Plant heights (cm) were significantly ( $p>0.05$ ) increased compared to the absolute control by the organic fertilizer materials. CPHA applied at a rate of 4 t/ha recorded the highest value of $(87.83 \mathrm{~cm})$ compared to control $(73.60 \mathrm{~cm})$ and NPK 20:10:10 $(75.67 \mathrm{~cm})$ respectively. Plant height of cocoa seedlings ranged from 73.60 to $87.83 \mathrm{~cm}$. Similar results were recorded for number of leaves and root lengths. The ash materials resulted in significantly $(P>0.05)$ higher number of leaves per plant and longer root length at six months after treatments application relative to control. This observation is in agreement with the result of [10] who reported similar increase in cashew seedling growth upon the use of fertilizer on some notable soils under cashew plantations in Nigeria. Also, the significant increases could be attributable to the fact that both CPHA and OPA are good sources of both macro and micro nutrients which encouraged better seedlings growth. This observation agreed with the earlier results of [4] who affirmed that organic manure and plant residues supported crop performance and increased crop yield. Generally, the application of CPHA and OPA at all levels of application progressively depressed the stem diameter $(\mathrm{cm})$ of cocoa seedlings compared to control and NPK 20:10:10. NPK (20:10:10) on the other hand, gave the highest mean value for stem diameter $(1.57 \mathrm{~cm})$ followed by CPHA $(1.49 \mathrm{~cm})$ applied at a rate of 4 tons/ha respectively. The depression in values of stem diameter of cocoa seedlings might be due to the fact that some of the nutrients applied to the soil were immobilized by soil micro-fauna, soil organic matter and other edaphic factors thereby making them unavailable to the seedlings. This observation is consistent with the earlier findings of [11] and [4] 
Table 3. Effect of fertilizer materials on the growth parameters of cocoa seedlings.

\begin{tabular}{|c|c|c|c|c|c|c|}
\hline $\mathrm{S} / \mathbf{N}$ & Treatments & $\begin{array}{l}\text { Plant-height } \\
\text { (cm) }\end{array}$ & Stem-diameter (cm) & Root-length (cm) & Number of leaves & Leaf-area $\left(\mathrm{cm}^{2}\right)$ \\
\hline 1 & CONTROL & $73.60^{f}$ & $1.44^{\mathrm{b}}$ & $36.40^{\mathrm{i}}$ & $43.33^{d}$ & $257.52^{\mathrm{h}}$ \\
\hline 2 & CPHA@1t/ha & $79.00^{\mathrm{e}}$ & $1.35^{\mathrm{e}}$ & $38.50^{\mathrm{g}}$ & $46.00^{\mathrm{a}}$ & $245.60^{\mathrm{i}}$ \\
\hline 3 & СРНА “2” & $79.17^{\mathrm{e}}$ & $1.38^{\mathrm{d}}$ & $36.67^{\mathrm{i}}$ & $42.67^{\mathrm{de}}$ & $239.39^{j}$ \\
\hline 4 & СРНА “3” & $85.23^{\mathrm{b}}$ & $1.40^{\mathrm{c}}$ & $37.23^{\mathrm{h}}$ & $44.00^{c}$ & $365.42^{\mathrm{a}}$ \\
\hline 5 & СРНА “4” & $87.83^{\mathrm{a}}$ & $1.49^{\mathrm{ab}}$ & $44.67^{\mathrm{e}}$ & $42.33^{\mathrm{de}}$ & $279.99^{\mathrm{g}}$ \\
\hline 6 & СРНА “5” & $74.13^{\mathrm{i}}$ & $1.37^{\mathrm{g}}$ & $50.00^{\mathrm{b}}$ & $45.33^{\mathrm{b}}$ & $302.89^{f}$ \\
\hline 7 & OPA “1” & $71.93^{\mathrm{j}}$ & $1.39^{\mathrm{d}}$ & $44.87^{\mathrm{e}}$ & $35.00^{\mathrm{h}}$ & $331.56^{\mathrm{d}}$ \\
\hline 8 & OPA “2” & $77.10^{\mathrm{f}}$ & $1.38^{\mathrm{d}}$ & $47.03^{\mathrm{c}}$ & $41.33^{\mathrm{f}}$ & $208.25^{\mathrm{k}}$ \\
\hline 9 & OPA “3” & $83.50^{c}$ & $1.40^{\mathrm{c}}$ & $45.83^{\mathrm{d}}$ & $27.67^{\mathrm{i}}$ & $359.81^{\mathrm{b}}$ \\
\hline 10 & OPA “4” & $80.43^{\mathrm{d}}$ & $1.42^{\mathrm{bc}}$ & $58.67^{\mathrm{a}}$ & $44.33^{\mathrm{c}}$ & $336.91^{\mathrm{c}}$ \\
\hline 11 & OPA “5” & $74.27^{\mathrm{h}}$ & $1.40^{\mathrm{C}}$ & $39.83^{f}$ & $41.67^{\mathrm{f}}$ & $141.12^{\mathrm{i}}$ \\
\hline 12 & NPK 20:10:10 & $75.67^{\mathrm{g}}$ & $1.57^{\mathrm{a}}$ & $38.67^{\mathrm{g}}$ & $39.00^{\mathrm{g}}$ & $313.24^{\mathrm{e}}$ \\
\hline
\end{tabular}

CPHA—cocoa-pod husk-ash; OPA—oil-palm bunch-ash; t/ha—-ton per hectare. Means that carry the same letters are not significantly different.

who observed a depression in the growth of cocoa and coffee seedlings respectively when fertilizer material such as cocoa pod husk ash, Urea and NPK fertilizers were used on cocoa and coffee seedlings. At six months after treatment application the CPHA at 3 tons/ha resulted to the highest mean leaf area value $\left(365.42 \mathrm{~cm}^{2}\right)$, this was followed by OPA @ 3 t/ha in descending order by OPA at 3 and 4 t/ha, OPA at 1 t/ha, NPK (20:10:10); CPHA at 5 t/ha, CPHA at 4 t/ha; control and CPHA at 1 t/ha respectively. CPHA applied at 2 t/ha recorded the least leaf area value. The influence of fertilizer materials on the dry matter yield and shoot to root ratio is presented in Table 4. Generally, there was significant increase ( $p>0.05)$ in the total dry matter yield (TDMY) of cocoa seedlings six months after treatment application due to addition of ash. The TDMY ranged between 26.95 to $34.32 \mathrm{~g}$. All the organic materials (CPHA and OPA) increased the root dry matter weight relative to control. The root dry matter (RDMW) weight was highest (9.20 g) when NPK (20-10-10) was used, and closely followed by OPA (8.37 Gg) at 1 t/ha, CPHA (8.33 g) at 4 t/ha, CPHA (8.07 g) at 5 t/ha, CPHA (7.93 g) at 3 t/ha; OPA (7.33 g) at 4 t/ha, CPHA (7.03 g) at 1 t/ha, control (6.87 g), OPA (6.30 g) at 3 t/ha and OPA (6.03 g) at 5 t/ha respectively.

The NPK (20-10-10) fertilizer though produced highest dry root weight. Except CPHA applied at 2 t/ha, other rates had comparable values relative to the inorganic fertilizer which was higher than control. The leaf dry matter yield of cocoa seedlings reduced in the order: CPHA at 4 t/ha $(13.19$ g) $>$ NPK (20:10:10) $(13.12$ g) $>$ CPHA at $3 \mathrm{t} / \mathrm{ha}(12.64 \mathrm{~g})>\mathrm{OPA}$ at $4 \mathrm{t} / \mathrm{ha}(12.52 \mathrm{~g})>\mathrm{CPHA}$ at $5 \mathrm{t} / \mathrm{ha}(12 / 45 \mathrm{~g})>(11.65 \mathrm{~g}) \mathrm{CPHA}$ at $1 \mathrm{t} / \mathrm{ha}(11.33 \mathrm{~g})>$ OPA at 2 t/ha (11.15 g), > OPA at 3 t/ha (11.10 g), > control (10.31 g), > OPA at 5 t/ha (9.09 g). Data on stem dried weight of the cocoa seedlings indicated that NPK and ash materials of plant origin were comparable in their values. The shoot to root ratio ranged from 2.65 to $3.44 \mathrm{~g}$. The highest value was recorded for OPA applied at a rate of 4 tons/ha; the lowest shoot to root ratio value was recorded with OPA at 1 t/ha. The shoot to root ratio was not significantly affected by the fertilizer materials irrespective of source. This implies that the fertilizer materials did not distort the proportion of shoot to the root in all the treatments. This observation is in agreement with the findings of [11] where different NPK fertilizer formulations were tried on the growth and dry matter yield of coffee seedlings in Ibadan. Similarly, the results of [12] on the use of plant residues for improving soil fertility, pod nutrients, growth and pod weight of Okra (Abelmoschus esculentum L.) also agree with the result of this present work.

At harvest, application of different fertilizer types affected leaf N, P, K, Ca and Mg (Table 5) respectively. NPK 20:10:10 produced a significant ( $<<0.05)$ effects on leaf $\mathrm{N}$ and $\mathrm{P}$ content of cocoa. This was followed by OPBA applied at $4 \mathrm{~kg} \mathrm{~N}$ ha $^{-1}$. However, this observation may be due to the high $\mathrm{N}$ content of NPK 20:10:10 which was readily made available for the use of the cocoa plant. Similarly, the low leaf N contents recorded by those plant treated with the ash might be due to low $\mathrm{N}$ contents of the material as a result of volatilization of $\mathrm{N}$ during burning process of the materials, an observation which was in agreement with the findings of [5]. The 
Table 4. Dry matter yield as influenced by fertilizer materials (g).

\begin{tabular}{|c|c|c|c|c|c|c|}
\hline $\mathbf{S} / \mathbf{N}$ & Fertilizer materials & RDMW. & LDMW & SDMW & TDMY & S/RR \\
\hline 1 & CONTROL & $6.87^{\mathrm{c}}$ & $10.31^{\mathrm{d}}$ & $9.77^{\mathrm{f}}$ & $26.95^{\mathrm{h}}$ & $2.92^{\mathrm{c}}$ \\
\hline 2 & CРHA@1 t/ha & $7.03^{\mathrm{bc}}$ & $11.33^{\mathrm{c}}$ & $11.20^{\mathrm{c}}$ & $29.56^{\mathrm{e}}$ & $3.20^{\mathrm{b}}$ \\
\hline 3 & СРНА “2” & $6.47^{\mathrm{d}}$ & $10.49^{\mathrm{e}}$ & $8.60^{\mathrm{g}}$ & $25.56^{\mathrm{i}}$ & $2.95^{\mathrm{c}}$ \\
\hline 4 & СРНА “3” & $7.93^{\mathrm{b}}$ & $12.64^{\mathrm{ab}}$ & $11.73^{\mathrm{ab}}$ & $32.30^{\mathrm{b}}$ & $3.07^{\mathrm{bc}}$ \\
\hline 5 & СРНА “4” & $8.33^{\mathrm{a}}$ & $13.19^{\mathrm{a}}$ & $12.60^{\mathrm{a}}$ & $34.12^{\mathrm{a}}$ & $3.10^{\mathrm{b}}$ \\
\hline 6 & СРНА “5” & $8.07^{\mathrm{ab}}$ & $12.45^{\mathrm{ab}}$ & $11.10^{\mathrm{c}}$ & $31.62^{\mathrm{c}}$ & $2.92^{\mathrm{c}}$ \\
\hline 7 & OPA “1” & $8.37^{\mathrm{ab}}$ & $11.65^{\mathrm{c}}$ & $10.60^{d}$ & $30.62^{\mathrm{d}}$ & $2.65^{\mathrm{d}}$ \\
\hline 8 & OPA “2” & $6.97^{\mathrm{d}}$ & $11.15^{\mathrm{cd}}$ & $10.37^{\mathrm{d}}$ & $28.49^{f}$ & $3.14^{\mathrm{b}}$ \\
\hline 9 & OPA “3” & $6.36^{\mathrm{e}}$ & $11.10^{\mathrm{cd}}$ & $10.07^{\mathrm{e}}$ & $27.47^{\mathrm{g}}$ & $3.36^{\mathrm{a}}$ \\
\hline 10 & OPA “4” & $7.33^{c}$ & $12.52^{\mathrm{ab}}$ & $12.67^{\mathrm{a}}$ & $32.52^{\mathrm{b}}$ & $3.44^{\mathrm{a}}$ \\
\hline 11 & OPA “5” & $6.03^{\mathrm{e}}$ & $9.09^{\mathrm{e}}$ & $8.40^{\mathrm{g}}$ & $23.52^{\mathrm{j}}$ & $2.90^{\mathrm{c}}$ \\
\hline 12 & NPK 20:10:10 & $9.20^{\mathrm{a}}$ & $13.12^{\mathrm{a}}$ & $12.0 \mathrm{a}^{\mathrm{b}}$ & $34.32^{\mathrm{a}}$ & $2.73^{\mathrm{e}}$ \\
\hline
\end{tabular}

CPHA—cocoa pod husk ash; OPA—oil palm ash; RDMW—root dry matter weight; LDMW—leaf dry matter weight; SDMW—stem dry matter weight; Total dry matter yield; S: RR—shoot to root ratio.

Table 5. Leaf nutrient elements (mg/kg) as influenced by the applied cocoa pod husk, Oil palm bunch ash and NPK fertilizer.

\begin{tabular}{ccccccc}
\hline S/N & Fertilizer materials & $\mathbf{N}$ & $\mathbf{P}$ & $\mathbf{K}$ & Ca & Mg \\
\hline 1 & CONTROL & $155.20^{\mathrm{k}}$ & $64.70^{\mathrm{j}}$ & $180.10^{\mathrm{k}}$ & $160.20^{\mathrm{k}}$ & $10.6^{\mathrm{g}}$ \\
2 & CPHA @ 1 t/ha & $210.20^{\mathrm{j}}$ & $80.10^{\mathrm{h}}$ & $260.90^{\mathrm{j}}$ & $164.90^{\mathrm{j}}$ & $13.53^{\mathrm{f}}$ \\
3 & CPHA “2” & $254.82^{\mathrm{h}}$ & $86.11^{\mathrm{ef}}$ & $301.30^{\mathrm{h}}$ & $308.60^{\mathrm{h}}$ & $15.60^{\mathrm{e}}$ \\
4 & CPHA “3” & $265.83^{\mathrm{g}}$ & $90.01^{\mathrm{d}}$ & $343.17^{\mathrm{g}}$ & $400.10^{\mathrm{f}}$ & $16.80^{\mathrm{d}}$ \\
5 & CPHA “4” & $310.42^{\mathrm{d}}$ & $95.35^{\mathrm{b}}$ & $360.50^{\mathrm{d}}$ & $34.12^{\mathrm{a}}$ & $18.30^{\mathrm{c}}$ \\
6 & CPHA “5” & $305.60^{\mathrm{de}}$ & $87.78^{\mathrm{e}}$ & $359.70^{\mathrm{de}}$ & $430.60^{\mathrm{e}}$ & $17.00^{\mathrm{d}}$ \\
7 & OPA “1” & $200.60^{\mathrm{j}}$ & $77.60^{\mathrm{i}}$ & $285.21^{\mathrm{i}}$ & $175.60^{\mathrm{i}}$ & $15.00^{\mathrm{e}}$ \\
8 & OPA “2” & $245.30^{\mathrm{i}}$ & $83.35^{\mathrm{g}}$ & $355.80^{\mathrm{f}}$ & $399.49^{\mathrm{g}}$ & $17.31^{\mathrm{d}}$ \\
9 & OPA “3” & $301.30^{\mathrm{c}}$ & $92.00^{\mathrm{c}}$ & $380.90^{\mathrm{c}}$ & $488.42^{\mathrm{c}}$ & $18.84^{\mathrm{c}}$ \\
10 & OPA “4” & $320.00^{\mathrm{b}}$ & $95.10^{\mathrm{b}}$ & $509.80^{\mathrm{a}}$ & $589.65^{\mathrm{a}}$ & $22.99^{\mathrm{a}}$ \\
11 & OPA “5” & $289.60^{\mathrm{f}}$ & $93.20^{\mathrm{bc}}$ & $506.10^{\mathrm{ab}}$ & $590.10^{\mathrm{b}}$ & $20.69^{\mathrm{b}}$ \\
\hline
\end{tabular}

CPHA—cocoa pod husk ash; OPA—oil palm ash; RDMW—root dry matter weight; LDMW—leaf dry matter weight; SDMW—stem dry matter weight; Total dry matter yield; S: RR—shoot to root ratio.

CPHA and OPA applied at the same rate of $4 \mathrm{~kg} \cdot \mathrm{N} \cdot \mathrm{ha}^{-1}$ produced a comparable result for P uptake. Conversely, relative to NPK 20:10:10 fertilizer and CPHA, OPBA applied at a rate of $4 \mathrm{~kg} \cdot \mathrm{N} \cdot \mathrm{ha}^{-1}$ recorded significantly (p < 0.05) higher leaf $\mathrm{K}, \mathrm{Ca}$ and $\mathrm{Mg}$ content respectively. The result of this present study confirmed the earlier claim of [9] that Oil palm bunch ash (OPBA) contained Ca, Mg and other essential micro-nutrients in addition to N, P, $\mathrm{K}$ and that its addition to cocoa plant significantly enhanced nutrient uptake.

\section{Conclusion}

Cocoa pod husk and oil palm bunch ash enhanced nutrients uptake, growth performance and dry matter yield of cocoa seedlings respectively. The ash materials had higher or comparable effects on the cocoa seedlings relative to the reference fertilizer (NPK 20:10:10) and could therefore be recommended for raising cocoa seedlings in the nursery. 


\section{Acknowledgements}

The authors wish to acknowledge the acting Executive Director of Cocoa Research Institute of Nigeria (CRIN), Ibadan for granting me permission to publish this work.

\section{References}

[1] Iremiren, G.O. (2011) Soil Fertility and Ageing Cocoa Farms in Nigeria. WCF Partnership Meeting and Round Table Session, Accra, 26-27 October 2011, 16.

[2] FAOSTAT (2011) Food and Agricultural Organization World Balance Sheet. www.fao.org/site.1

[3] Ogunlade, M.O. and Aikpokpodion, P.O. (2010) Physicochemical Properties of Selected Soils in Three Cocoa Growing Ecologies of Nigeria. Proceedings of the 44th Annual Conference of Agricultural Society of Nigeria, Lautech, 88-110.

[4] Akanbi, O.S.O., Ojeniyi, S.O., Famaye, A.O., Ipinmoroti, R.R., Ibiremo, O.S., Oloyede, A.A., Taiwo, N., Aderolu, I.A. and Orisasona, T.M. (2013) Utilization of Ashed Cocoa Pod Husk and Urea Fertilizer on Growth and Dry Matter Yield of Coffee on Alfisol in Ibadan. Nigerian Journal of Soil Science, 23, 10-16.

[5] Ajayi, C.A., Awodun, M.A. and Ojeniyi, S.O. (2007) Effect of Cocoa Husk ash on Growth and Stem Nutrient Uptake of Kola Seedlings. Asian Journal of Agricultural Research, 1, 27-30.

[6] IITA (International Institute of Tropical Agriculture) (1981) Automated and Semi Automated Method for Soil and Plant Analysis. Manual Series No. 7, IITA, Ibadan, Science 18/2008.

[7] Egbe, N.E., Ayodele, E.A. and Obatolu, C.R. (1989) Soil Nutrition of Cocoa, Kola, Coffee, Cashew and Tea. Progress in Tree Crop Research, 2, 28-38

[8] Owolabi, O., Adeleye, A., Oladejo, D.T. and Ojeniyi, S.O. (2003) Effect of Wood Ash on Soil Fertility and Crop Yield in Southwest Nigeria. Nigerian Journal of Soil Science, 13, 15-60.

[9] Akanbi, O.S.O., Ojeniyi, S.O., Famaye, A.O., Oloyede, A.A., Oyewumi, I.K., Ayegbonyin, K., Adejobi, K.B. and Idrisu, M. (2014) Soil Nutrients and Cocoa Seedlings Performance as Influenced by Plant Residue Ash and NPK Fertilizer Addition on a Depleted Soil in Ibadan. International Research Journal of Agricultural Science and Soil Science, 1, 1-4.

[10] Ibiremo, O.S. and Fagbola, O. (2008) Effect of Phosphate Fertilizer and Arbuscular Mycorrhizal Fungi Inoculation on the Growth of Cashew Seedlings in Two Soils in Nigeria. Nigerian Journal of Soil Science, 18, 148-156.

[11] Ibiremo, O.S., Akanbi, O.S.O., Oloyede, A.A and Adebowale, L.A. (2012) Evaluation of NPK Fertilizer Formulations on the Growth and Dry Matter Yield of Coffee Seedlings in Ibadan, South-Western, Nigeria. Nigerian Journal of Soil Science, 23, 22-26.

[12] Moyin-Jesu, E.I. (2007) Use of Plant Residues for Improving Soil Fertility, Pod Nutrients, Growth and Pod Weight of Okra (Abelmoschus esculentum L.). Bioresource Technology, 98, 2057-2064. http://dx.doi.org/10.1016/j.biortech.2006.03.007 
Scientific Research Publishing (SCIRP) is one of the largest Open Access journal publishers. It is currently publishing more than 200 open access, online, peer-reviewed journals covering a wide range of academic disciplines. SCIRP serves the worldwide academic communities and contributes to the progress and application of science with its publication.

Other selected journals from SCIRP are listed as below. Submit your manuscript to us via either submit@scirp.org or Online Submission Portal.
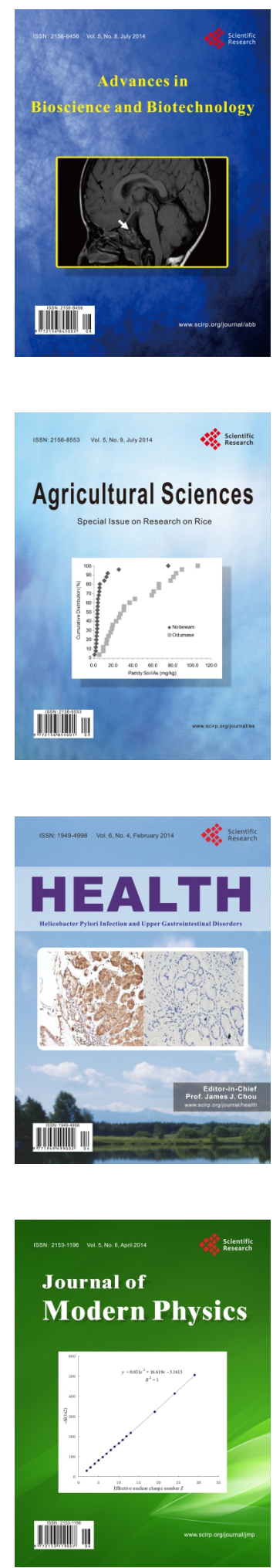
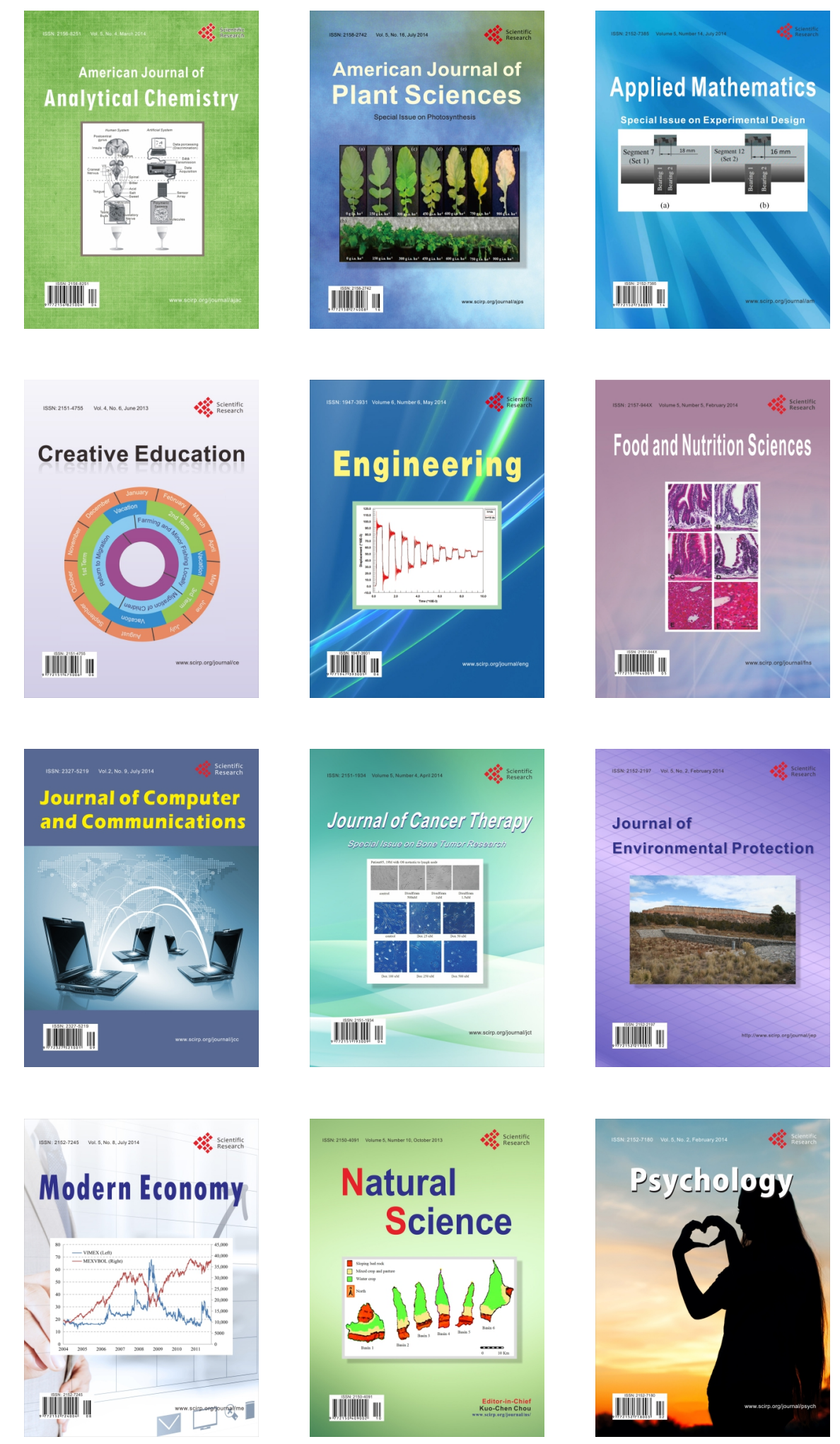